\title{
ANALISIS FAKTOR-FAKTOR YANG MEMPENGARUHI TINGKAT UNDERPRICING PADA PERUSAHAAN GO PUBLIC YANG TERDAFTAR DI BURSA EFEK INDONESIA (BEI) TAHUN 2012-2014
}

\author{
Kunthi Widjaya \\ artakunthi@gmail.com \\ Universitas Ahmad Dahlan \\ Tina Sulistiyani \\ tina_uad@yahoo.com \\ Universitas Ahmad Dahlan
}

\begin{abstract}
ABSTRAK
This study aims to determine the factors that influence underpricing. The variables studied were earnings per share (EPS), debt to equity ratio (DER), underwriter reputation, auditor reputation, industry type. Which method used in this research is purposive sampling, obtained as many samples 47 companies out of a population of 77 companies. This research was conducted with using multiple linear regression analysis with a significance level of 5\%. The results of the study concluded that earning per share (EPS) variable successfully demonstrated a negative influence on the current underpricing of shares Initial public offering, debt to equity ratio (DER) failed to show there is a negative influence on the level of underpricing, the reputation of the underwriter is not managed to show a positive influence on underpricing, reputation. The auditor failed to show a negative effect on underpricing, and industry type variables did not work out negative effect on underpricing.
\end{abstract}

Keywords: Initial Public Offering (IPO); Earnings Per Share (EPS); Debt to Equity Ratio (DER); Underpricing; Underwriter Reputation; Auditor Reputation; Industry Type.

\section{PENDAHULUAN}

Dalam menjalankan usahanya suatu perusahaan tentu memiliki kebutuhan modal untuk kelangsungan perkembangan operasional usahanya. Kebutuhan modal ini terkadang menjadi salah satu permasalahan bagi manajemen perusahaan karena modal adalah kebutuhan pokok bagi perusahaan untuk mempertahankan semua unit usaha yang berada didalam lingkungan perusahaan tersebut. Dalam hal ini manajemen memiliki wewenang untuk memilih tambahan modal yang diperlukan perusahaan alternatif tersebut dapat dilakukan dengan cara menambah hutang atau dengan menambah jumlah kepemilikan saham dengan menerbitkan saham baru. Apabila cara yang dipilih adalah dengan menambah jumlah kepemilikan saham maka perusahaan dapat menempuh beberapa cara, antara lain: Pertama, menjual langsung kepada pemegang saham yang sudah ada sebelumnya. Kedua, menjual kepada karyawan melalui Employee Stock Ownership (ESOP). Ketiga, menambah saham lewat deviden yang tidak dibagi (dividend reinvestment plan). Keempat, menjual langsung kepada pembeli tunggal (misalnya, investor institusional). Kelima, menjual kepada publik lewat pasar saham (Jogiyanto, 2000). Menjual saham kepada publik melalui pasar moda disebut dengan istilah go public.

Perusahaan dapat melaksanakan mekanisme go public dengan menjual sahamnya pertama kali pada penawaran perdana atau initial public offering (IPO) di pasar perdana. Harga saham akan 
ditentukan oleh emiten dan underwriter. Emiten merupakan perusahaan yang menawarkan atau menjual efek kepada masyarakat melalui pasar modal, sedangkan underwriter adalah pihak yang membuat kontrak dengan emiten untuk melakukan penawaran umum. Sebelum menawarkan sekuritas di pasar perdana, perusahaan sebelumnya harus memberikan informasi (prospektus) mengenai perusahaan secara detail (Tandelilin, 2010). Karena pada umumnya investor memiliki informasi terbatas mengenai perusahaan. Prospektus bertujuan untuk memberikan informasi mengenai kinerja perusahaan, sehingga investor bisa mengetahui dan memprediksi prospek perusahaan di masa mendatang.

Informasi prospektus dapat dibagi menjadi dua, yaitu informasi akuntansi dan informasi non akuntansi. Informasi akuntansi terdiri atas laporan keuangan yang terdiri dari neraca, perhitungan laba rugi, laporan arus kas, dan penjelasan laporan keuangan. Sedangkan informasi non akuntansi adalah informasi selain laporan keuangan seperti underwriter, reputasi auditor, konsultan hukum, nilai penawaran saham, presentase saham yang ditawarkan, umur perusahaan, jenis industri dan informasi lainya. Investor maupun perusahaan harus menggunakan informasi yang ada dalam ketentuan ini ketika mereka membuat keputusan investasi di pasar modal.

Bagi emiten dan underwriter risiko yang dihadapi pada IPO adalah pada penentuan harga saham dan waktu yang tepat untuk go public. Underwriter harus mempelajari dan meneliti keadaan atau kinerja emiten kemudian memproyeksi kemampuan dan minat calon investor terhadap saham yang dijamin emisinya. Underwriter harus mempertimbangkan jenis perjanjian penjaminan emisi yang ditawarkan pada emiten, karena underwriter menghadapi kemungkinan tidak lakunya saham yang dijual. Jika hal ini terjadi maka emiten tidak akan mendapatkan dana seperti yang diharapkan. Bila Harga saham pada penawaran saham perdana ditentukan berdasarkan kesepakatan antara emiten dan penjamin emisi (underwriter).

Masalah yang sering kali timbul saat Initial Public Offering (IPO) adalah apabila harga penawaran saham saat IPO cenderung lebih rendah dibandingkan dengan harga yang terjadi pada hari pertama diperdagangkan di pasar sekunder (Bursa Efek) (Purbarangga, 2013). Terjadinya selisih positif antara harga penawaran dan harga penutupan tersebut disebut sebagai underpricing. Perusahaan yang melakukan penawaran perdana menghindari terjadinya underpricing, karena underpricing membuat perusahaan tidak bisa mendapatkan dana yang maksimal dari penjualan saham perdananya.

Menurut Beatty dalam Hayati (2013) Kondisi underpricing merugikan untuk perusahaan yang melakukan go public, karena dana yang diperoleh dari go public tidak maksimum. Sebaliknya jika terjadi overpricing, maka investor yang akan merugi, karena mereka tidak menerima initial return yaitu keuntungan yang diperoleh pemegang saham karena perbedaan harga saham yang dibeli di pasar perdana saat IPO dengan harga jual yang bersangkutan di hari pertama di pasar sekunder. Para pemilik perusahaan menginginkan agar meminimalisasikan situasi underpricing, karena terjadinya underpricing akan menyebabkan transfer kemakmuran dari pemilik kepada para investor.

Trisnawati (1999) dalam penelitian Kurniawan (2012) memfokuskan penelitian pada informasi keuangan dan non keuangan pada prospektus terhadapreturn di Bursa Efek Indonesia. Faktor keuangan yang digunakan dalam penelitian adalah profitabilitas perusahaan yang diukur dengan Rate of Return On Asset (ROA) dan financial leverage. Faktor-fakto non keuangan adalah reputasi auditor, reputasi penjamin emisi, dan prosentase saham. Hasilnya 
menunjukkanbahwa umur perusahaan berpengaruh signifikan dan positif dengan initial return.

Emiten mengusahakan untuk meminimalisir underpricing, akan tetapi pada kenyataannya masih terdapat banyak perusahaan yang mengalami underpricing pada saat penawaran saham perdana. Maka perlu diketahui faktor-faktor yang dapat mempengaruhi terjadinya underpricing terhadap perusahaan yang akan go public. Meskipun studi tentang underpricing telah banyak dilakukan, namun penelitian di bidang ini masih dianggap masalah yang menarik untuk diteliti karena adanya inkonsistensi hasil penelitian.

Tujuan dari penelitian ini di antaranya:

1. Untuk mengetahui pengaruh variabel keuangan earning per share (EPS) terhadap tingkat underpricing pada perusahaan yang melakukan IPO.

2. Untuk mengetahui pengaruh variabel keuangan debt to equity ratio (DER) terhadap tingkat underpricing pada perusahaan yang melakukan IPO.

3. Untuk mengetahui pengaruh variabel non keuangan yaitu reputasi underwriter terhada tingkat underpricing pada perusahaan yang melakukan IPO.

4. Untuk mengetahui pengaruh variabel non keuangan reputasi auditor terhadap tingkat underpricing pada perusahaan yang melakukan IPO.

5. Untuk mengetahui pengaruh variabel non keuangan jenis industri terhadap tingkat underpricing pada perusahaan yang melakukan IPO.

6. Untuk mengetahui pengaruh secara simultan variabel keuangan yaitu earning per share (EPS), debt to equity (DER) dan variabel non keuangan yaitu reputasi underwriter, reputasi auditor, jenis industri terhadap tingkat underpricing pada perusahaan yang melakukan IPO.

\section{REVIEW LITERATUR DAN HIPOTESIS}

\section{Landasan Teori}

1. Pasar Modal

Pasar modal (capital market) merupakan pasar untuk berbagai instrumen keuangan jangka panjang yang bisa diperjualbelikan, baik surat hutang (obligasi), ekuiti (saham), reksadana, instrument derivative maupun instrumen lainnya. Pasar modal merupakan sarana pendanaan bagi $\mathrm{p}$ erusahaan maupun institusi lain (pemerintah), dan sebagai sarana bagi kegiatan berinvestasi. Dengan demikian pasar modal memfasilitasi berbagai sarana dan prasarana kegiatan jualbeli dan kegiatan terkait lainnya. Pasar modal bertindak sebagai penghubung antara para investor dengan perusahaan ataupun institusi pemerintah melalui perdagangan instrumen keuangan jangka panjang, seperti obligasi saham dan sebagainya (Martalena, 2011).

2. Saham

\begin{tabular}{llr}
\multicolumn{1}{c}{ Saham adalah surat bukti } \\
kepemilikan atau surat bukti \\
penyertaan suatu perusahaan yang \\
mengeluarkannya (emiten) & yang \\
kepemilikannya tidak memberikan \\
suatu keistimewaan
\end{tabular}
(Asakdiyah, 2006).

3. Initial Public Offering (IPO)

Initial Public Offering (IPO) merupakan kegiatan yang dilakukan perusahaan dalam rangka penawaran umum penjualan saham perdana (Ang, 1997).

\section{Underpricing}

Underpricing yaitu harga saham hari pertama di pasar sekunder lebih tinggi dari harga saham penawaran perdananya (Triani dalam Aini, 2013). 
5. Earning Per Share (EPS)

Brigham (2001) berpendapat bahwa laba per lembar saham (EPS) adalah kemampuan perusahaan untuk mendistribusikan pendapatan kepada pemegang saham. Hal ini mencerminkan semakin besar keberhasilan usaha yang dilakukannya.

\section{Debt to Equity Ratio (DER)}

DER yaitu kemampuan perusahaan dalam memenuhi seluruh kewajibannya yang ditunjukkan oleh beberapa bagian modal sendiri yang digunakan untuk membayar hutang (Kurniawan, 2007).

\section{Underwriter}

Underwriter menurut UndangUndang Pasar Modal No. 8 Tahun 1995 adalah pihak yang membuat kontrak dengan emiten untuk melakukan penawaran umum bagi kepentingan emiten dengan atau tanpa kewajiban untuk membeli sisa efek yang terjual.

8. Reputasi Auditor

$$
\text { Reputasi auditor sangat }
$$

berpengaruh pada kredibilitas laporan

keuangan ketika perusahaan melakukan IPO. Informasi yang ada dalam prospektus tingkat kepercayaannya tergantung dari pihak auditor yang melakukan audit. Semakin tinggi reputasi auditor maka semakin baik tingkat kepercayaan informasi yang ada dalam prospektus (Hartono dalam Aini, 2013).

\section{Jenis Industri}

Variabel jenis industri mungkin saja mempengaruhi underpricing karena tiap industri memiliki risiko dan tingkat ketidakpastian yang berbeda sehingga dapat mempengaruhi investor dalam mengambil keputusan investasi (Yolana, 2005).

\section{Penelitian Terdahulu}

Aini (2013) dalam penelitiannya menyatakan bahwa dengan sampel sebanyak 78 perusahaan yang listing di BEI periode tahun 2007-2011 hanya variabel reputasi auditor yang berpengaruh terhadap underpricing sedangkan variabel lainya tidak mempengaruhi tingkat underpricing. Variabel reputasi auditor mempunyai hubungan negatif, yang artinya bahwa perusahaan IPO yang menggunakan auditor bereputasi tinggi akan menyebabkan tingkat underpricing rendah. Kurniawan (2012) dalam penelitiannya dengan menggunakan metode purposive sampling terhadap 51 perusahaan yang melakukan IPO di bursa efek Indonesia selama periode 2008 sampai dengan 2010 dengan menggunakan analisis linier berganda menunjukkan bahwa DER, EPS, dan Price Earning Ratio (PER) tidak berpengaruh signifikan baik secara parsial maupun serempak terhadap tingkat underpricing.

\section{Hipotesis}

H1: Ada pengaruh secara signifikan variabel keuangan Earning Per Share (EPS) terhadap tingkat underpricing.

$\mathrm{H} 2$ : Ada pengaruh secara signifikan variabel keyangan Debt To Equity Ratio (DER) terhadap tingkat underpricing.

H3: Ada pengaruh secara signifikan variabel non keuangan reputasi underwriter terhadap tingkat underpricing.

H4: Ada pengaruh secara signifikan variabel non keuangan reputasi auditor terhadap tingkat underpricing.

H5: Ada pengaruh secara signifikan variabel non keuangan jenis industri terhadap tingkat underpricing. 
H6: Ada pengaruh secara simultan variabel keuangan Earning Per Share (EPS), Debt to Equity Ratio (DER) dan variabel non keuangan reputasi underwriter, reputasi auditor, jenis industri terhadap tingkat underpricing.

\section{METODE PENELITIAN}

\section{Populasi dan Sampel}

Populasi adalah wilayah generalisasi yang terdiri atas obyek maupun subyek tertentu yang yang mempunyai kualitas dan karakteristik tertentu yang diterapkan oleh peneliti untuk dipelajari dan kemudian ditarik kesimpulannya (Sugiyono, 2010). Populasi dalam penelitian ini adalah seluruh perusahaan yang terdaftar di bursa efek Indonesia periode 2012-2014 dimana terdapat 77 perusahaan yang melakukan initial public offering (IPO). Sedangkan sampel menurut Sugiyono (2010) mengatakan bahwa sampel adalah bagian dari jumlah karakteristik yang dimiliki populasi tersebut. Dalam hal ini penulis menentukan sampel dengan metode purposive sampling. Purposive sampling merupakan teknik pengambilan sampel dengan pertimbangan dan kriteria tertentu. Pertimbangan tersebut didasarkan atas kepentingan dan tujuan penelitian (Purwanto, 2004). Adapun kriteria yang digunakan dalam penentuan sampel ini adalah sebagai berikut :

1. Sampel merupakan perusahaan yang melakukan IPO dan listing di BEI periode tahun 2012-2014.

2. Perusahaan tersebut tidak mengalami overpricing.

3. Perusahaan tersebut memiliki persediaan data yang lengkap. Yang terdiri dari harga saham perdana, harga saham penutupan pada hari pertama, tanggal listing, nama underwriter, nama auditor, tahun berdiri, dan rasiorasio yang diperlukan.
4. Data perusahaan khususnya EPS dan DER tidak memiliki nilai negatif

\section{Definisi Operasional}

1. Variabel Independen

a. Earning Per Share (X1)

$\begin{array}{rlr}\text { Semakin } & \text { besar } & \text { EPS } \\ \text { mencerminkan } & \text { resiko } & \text { dan }\end{array}$ performance perusahaan, semakin mapan perusahaan, semakin tinggi EPS yang dimilikinya dengan demikian semakin sedikit initial return yang diperoleh. Untuk menghitung EPS dapat digunakan rumus sebagai berikut:

$$
\text { EPS }=\frac{\text { Laba Bersih }}{\Sigma \text { lembar saham yang beredar }}
$$

b. Debt to Equity Ratio (X2)

$$
\begin{aligned}
& \text { Semakin besar DER maka } \\
& \text { akan mencerminkan resiko } \\
& \text { perusahaan yang relatif tinggi, } \\
& \text { sehingga para investor cenderung } \\
& \text { menghindari saham-saham yang } \\
& \text { memiliki nilai DER tinggi. Untuk } \\
& \text { menghitung rasio DER dapat } \\
& \text { digunakan rumus sebagai berikut: }
\end{aligned}
$$

$$
\text { DER }=\frac{\text { Total Debt }}{\text { Total Equity }}
$$

c. Reputasi Underwriter (X3)

Reputasi underwriter diukur dengan menggunakan variabel dummy. Pengukuran dengan memberi nilai 1 untuk underwriter yang bereputasi tinggi dan 0 untuk sebaliknya. Standar pengukuran reputasi underwriter yaag bereputasi tinggi berdasarkan perangkingan big five total frequency (Sulistio dalam Aini, 2013).

d. Reputasi Auditor (X4)

Untuk menentukan reputasi auditor dapat dilihat berdasarkan standar pengukuran dalam KAP yang menjadi partner dari auditor The Big Four (Sulistio dalam Aini, 2013). Pengukuran variabel reputasi auditor menggunakan variabel dummy. Penentuan reputasi auditor 
dengan menggunakan skala 1 untuk auditor yang bereputasi baik dan 0 untuk auditor yang memiliki reputasi kurang baik.

e. Jenis Industri (X5)

Pengukuran variabel jenis industri menggunakan variabel dummy. Penentuan jenis industry menggunakan skala 1 untuk industri manufaktur dan 0 untuk industri bukan manufaktur.

2. Variabel Dependen

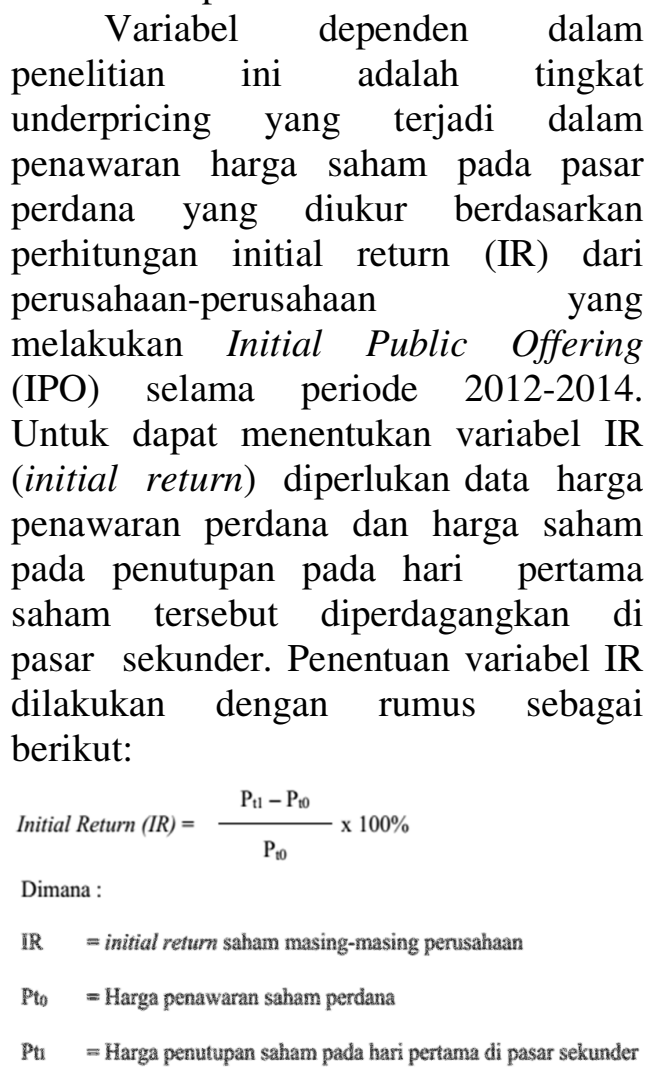

\section{Uji Instrumen}

1. Uji Analisis Statistik Deskriptif

Statistik deskriptif adalah alat statistik yang digunakan untuk menjelaskan dan menganalisis data dengan cara menggambarkan data yang telah terkumpul tanpa maksud untuk membuat kesimpulan secara umum.
2. Uji Asumsi Klasik

a. Normalitas

Uji normalitas adalah alat analisis residual untuk mengetahui apakah suatu residual berasal dari populasi yang sama. Jika residual berdistribusi normal maka statistik yang digunakan adalah statistic parametik dan jika residual berdistribusi tidak normal maka diolah dengan statistik nonparametric. Mendeteksi normalitas dilakuakan dengan uji statistic Jarque-Bera test. Dasar pengambilan keputusanya bila nilai signifikan lebih besar dari 0,05 maka data berdistribusi normal (Kusuma, 2012).

b. Heteroskedastisitas

Uji heteroskedastisitas dilakukan untuk menguji apakah ada kesamaan dalam regresi antar varian variabel. Jika varian residual suatu pengamatan ke pengamatan lain tetap maka disebut homoskedastisitas dan jika berbeda disebut heteroskedastisitas. Model regresi yang diharapkan adalah ketika regresi terjadi homoskedastisitas atau tidak terjadi heteroskedastisitas. Dalam penelitian ini untuk mengetahui apakah regresi ini terjadi heteroskedastisitas atau tidak maka dilakukan pengujian dengan metode white. Jika nila Chi-Square lebih besar dari $\alpha$, maka terjadi heteroskedastisitas. Sebaliknya, jika Chi-Square lebih kecil dari $\alpha$ maka tidak terjadi heteroskedastisitas.

c. Autokorelasi

Uji Autokorelasi bertujuan untuk menguji apakah suatu model regresi linear adalah korelasi antara kesalahan pengganggu pada periode $t$ dengan kesalahan pengganggu pada perioda $\mathrm{t}-1$ atau sebelumnya (Ghozali, 2011). Autokorelasi muncul karena observasi yang berurutan sepanjang waktu berkaitan 
satu sama lain. Uji yang digunakanuntuk mendeteksi adanya autokorelasi adalah Durbin Watson (DW). Kriteria pengambilan kesimpulan dalam uji Durbin Watson (DW) adalah sebagai berikut:

$0<$ DW $<$ dl $=$ Terjadi Autokorelasi $\mathrm{dl} \leq \mathrm{DW} \leq \mathrm{du}=$ Tidak dapat disimpulkan

$\mathrm{du}<\mathrm{DW}<4-\mathrm{du}=$ Tidak ada autokorelasi

4-du $\leq \mathrm{DW} \leq 4-\mathrm{dl}=$ Tidak dapat disimpulkan

d. Multikolinieritas

Uji multikolinearitas bertujuan untuk menguji apakah model regresi ditemukan adanya korelasi antar variabel independen. Menurut Ghozali dalam Maryoto (2007), untuk mendeteksi ada atau tidaknya Multikolinearitas di dalam model regresi adalah sebagai berikut: Nilai $\mathrm{R}^{2}$ yang dihasilkan oleh estimasi model regresi empiris sangat tinggi tetapi secara individual variabelvariabel bebas banyak yang tidak signifikan mempengaruhi variabel terikat. Menganalisis matrik korelasi variabel-variabelbebas. Jika antar variabel bebas ada korelasi yang cukup tinggi (di atas 0,90) maka hal ini membuktikan indikasi adanya multikolinearitas.

\section{Teknik Analisis Data}

1. Analisis Regresi Berganda

$$
\begin{aligned}
& \mathrm{Y}=\alpha+\mathrm{b} 1 \mathrm{X} 1+\mathrm{b} 2 \mathrm{X} 2+\mathrm{b} 3 \mathrm{X} 3+\mathrm{b} 4 \mathrm{X} 4 \\
& +\mathrm{b} 5 \mathrm{X} 5 \\
& \text { Keterangan : } \\
& \mathrm{Y}=\text { Underpricing } \\
& \mathrm{A}=\text { Konstanta } \\
& \mathrm{b} 1, \mathrm{~b} 2, \mathrm{~b} 3, \mathrm{~b} 4, \mathrm{~b} 5=\text { Koefisien regresi } \\
& \mathrm{X} 1=\text { Earning per Share (EPS) } \\
& \mathrm{X} 2=\text { Debt to Equity Ratio (DER) } \\
& \mathrm{X} 3=\text { Reputasi Underwriter } \\
& \mathrm{X} 4=\text { Reputasi Auditor } \\
& \mathrm{X} 5=\text { Jenis Industri }
\end{aligned}
$$

\section{Uji Hipotesis}

1. Uji Parsial (Uji T)

Uji statistik $\mathrm{t}$ dilakukan untuk menguji pengaruh suatu variabel independen secara individual dalam menerangkan variasi variabel dependen (Ghozali dalam Kristiantari, 2013). Artinya dapat diketahui variabel independen tersebut merupakan penjelas yang signifikan atau tidak terhadap variabel dependen. Dalam ujj hipotesis, ditolak atau diterimanya $\mathrm{H} 1$ tergantung dari besarnya $\alpha$ yang digunakan. Semakin kecil $\alpha$ berarti semakin kecil probabilitas menolak hipotesis yang benar dan semakin besar $\alpha$ berarti semakin besar probabilitas menolak hipotesis yang benar. Selain itu keputusan untuk menolak $\mathrm{H} 1$ juga bisa dilakukan dengan menggunakan uji hipotesis berdasarkan probabilitas statistik $t$ dengan asumsi bahwa residual mempunyai distribusi normal. Nilai probabilitas ini disebut juga nilai $\mathrm{p}$ ( $\mathrm{p}$ - value) atau tingkat signifikansi marginal (marginal significance level). Keputusan menolak H1 jika absolut statistic $t$ hitung lebih besar dari nilai kritis t dari distribusi table t. Sementara itu pada prosedur uji probabilitas statistic $t$ atau nilai $p$ hanya membandingkan nilai probabilitas $\mathrm{p}$ dengan nilai signifikansi $\alpha$. Jika nilai signifikansi $\mathrm{p}<\alpha$, maka menolak hipotesis nol atau menerima hipotesis alternatif dan sebaliknya jika nilai probabilitas $\mathrm{p}>\alpha$ maka menerima hipotesis nol dan menolak hipotesis alternatif.

\section{Uji Simultan (Uji F)}

Umumnya pada penelitian lebih banyak menggunakan data sampel daripada data populasi. Dari sampel yang diambil kemudian dapat dijadikan sebagai alat verifikasi kebenaran populasi. Dalam statistika, hipotesis yang ingin diuji kebenaranya tersebut biasanya dibandingkan. Untuk melihat 
kemaknaan model garis regresi dapat dilakukan dengan pengujian simultan. Pengujian secara simultan dapat diperoleh dengan menggunakan uji $\mathrm{F}$. Interprestasi dari uji $\mathrm{F}$ ini adalah, jika nilai $\mathrm{p}<\alpha(0,05 \%)$, maka secara simultan terdapat pengaruh antara variabel independen dengan variabel dependen dan begitupun sebaliknya jika nilai $\mathrm{p}>\alpha(0,05 \%)$, maka secara simultan tidak terdapat pengaruh antara variabel independen dengan variabel dependen.

\section{HASIL PENELITIAN DAN PEMBAHASAN}

\section{Hasil Penelitian}

1. Hasil Uji Statistik Deskriptif

\begin{tabular}{|c|c|c|c|c|c|c|}
\hline \\
\hline & $\overline{\mathbf{Y}}$ & $\mathrm{X} 5$ & $\mathrm{X} 4$ & $\mathrm{X3}$ & $\mathrm{X} 2$ & $\mathrm{X} 1$ \\
\hline \begin{tabular}{|l} 
Mean \\
\end{tabular} & -1.783128 & 0.382979 & 0.212766 & 0.063830 & -0.151592 & 2.912820 \\
\hline \begin{tabular}{|l|} 
Mediaan \\
\end{tabular} & -1.810109 & 0.000000 & 0.000000 & 0.000000 & -0.174353 & 3.295837 \\
\hline 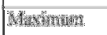 & 036460 & $10000 \%$ & 1 1.600 & Inowow & 291230 & 4564348 \\
\hline Moninuming & 4,52709 & 0 & 2060000 & 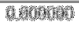 & $-2,25725$ & -1.60438 \\
\hline SMe Der & $1,24 \% 13$ & 0.4813*6 & 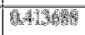 & (254\%) & 3156028 & 1.378981 \\
\hline 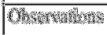 & 4? & 絭 & 4 & 解 & 䨔贯 & की? \\
\hline
\end{tabular}

Underpricing $(\mathrm{Y})$ diukur dengan initial return merupakan selisih antara harga penutupan saham (closing price) dengan harga penawaran umum (offering price) dibagi dengan harga penawaran umum (offering price). Rata-rata (mean) tingkat underpricing (Y) saham dalam penelitian ini sebesar $-1,7831$ berarti minus (178,3\%). Tingkat underpricing yang paling rendah sebesar $-4,5272$ berarti minus $(452,7 \%)$ terjadi pada PT Dharma Satya Nusantara Tbk (DSNG). Tingkat underpricing (Y) tertinggi sebesar 0,3654 berarti $36,54 \%$ terjadi pada PT Bekasi Fajar Industrial Tbk (BEST).

Earning Per Share (EPS) yang diukur dengan cara laba bersih dibagi dengan jumlah lembar saham yang beredar, nilai rata-rata EPS dalam penelitian ini sebesar 2,9125 berarti 291,25\%. Nilai EPS paling rendah adalah minus $(160,9)$ yang terjadi pada perusahaan PT Sitara Propertindo Tbk
(TARA). Nilai maksimal EPS 4,564 yang berarti $(456,4 \%)$ pada PT Dharma Satya Nusantara Tbk (DSNG). Dalam penelitian ini standar deviasi EPS sebesar 1,3798 artinya bahwa variabel ini memiliki penyimpangan sebesar $137,9 \%$.

Debt to Equity Ratio (DER) diukur dengan total debt dibagi total equity. Nilai rata-rata DER minus $(15,15 \%)$. Standar deviasi DER dalam penelitian ini sebesar 1,1060 yang berarti bahwa nilai penyimpangan variabel DER sebesar $110,6 \%$. Tingkat DER paling tinggi terjadi pada Bank Agris (AGRS) dengan nilai 2,0412 berarti $204,1 \%$ dan tingkat DER terendah terjadi pada PT Victoria Investama Tbk (VICO) sebesar minus $(252,5 \%)$.

Reputasi underwriter dinilai menggunakan variabel dummy, berdasarkan statistik deskriptif nilai rata-rata (mean) sebesar 0,0638 berarti $6,38 \%$ dari total sampel perusahaan menggunakan underwriter yang memiliki reputasi tinggi sesuai dengan 5 besar penjamin emisi teraktif dalam 50 most active brokerage house monthly IDX statistic berdasarkan total frekuensi perdagangan. Sedangkan 93,62\% menggunakan underwriter yang tidak memiliki nilai reputasi tinggi. Nilai standar deviasi underwriter sebesar 0,2470 artinya bahwa variabel ini memiliki nilai penyimpangan sebesar $24,7 \%$.

Nilai rata-rata reputasi auditor sebesar $21,27 \%$ dari total sampel perusahaan menggunakan auditor yang termasuk dalam the big four auditors. Sedangkan $78,73 \%$ perusahaan menggunakan auditor yang tidak termasuk di dalam the big four auditors dan memiliki nilai penyimpangan sebesar 0,4136 atau sebesar 41,36\%.

Dilihat dari jenis industri yang memiliki rata-rata 0,3829 atau sebesar $38,29 \%$ adalah perusahaan yang termasuk dalam kategori perusahaan 
manufaktur atau perusahaan yang menjalankan proses pembuatan produk dan sebanyak $61,71 \%$ merupakan perusahaan bukan manufaktur seperti pendidikan, hiburan, penginapan, pemerintahan, pelayanan, keuangan, dan kesehatan. Selain itu standar deviasi variabel jenis industri memiliki nilai sebesar 0,4913 berarti bahwa jenis industri ini memiliki penyimpangan sebesar $49,13 \%$.

2. Hasil Uji Asumsi Klasik

a. Normalitas

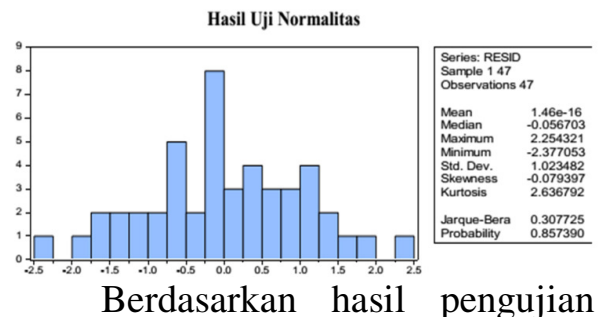
normalitas tabel di atas menunjukkan bahwavariabel EPS (ln X1), DER (ln X2) memiliki Asymp Sig di atas tingkat signifikansi 5\%. Dalam penelitian ini tingkat signifikansi variabel tersebut sebesar 0,857 $(85,7 \%)$ dapat disimpulkan bahwa data berdistribusi normal. Sedangkan variabel reputasi underwriter (X3), reputasi auditor (X4), dan jenis industri (X5) merupakan variabel dummy.

b. Autokorelasi

\begin{tabular}{|c|c|}
\multicolumn{2}{|c}{ Hasil Uji Autokorelasi } \\
\hline Durbin Watson & 2,661 \\
\hline
\end{tabular}

Nilai DW sebesar 2,661 akan dibandingkan dengan nilai tabel menggunakan signifikansi $5 \%$, jumlah sampel 47 (n) dan jumlah variabel independen 5 (k-5) maka didapat batas atas (du) 1,7736 dari tabel Durbin Watson. Oleh karena DW 2,661 lebih besar dari batas atas (du) 1,7736 dan kurang dari (4-1,7736) atau $1,7736<$ $2,661<(4-1,7736), \quad$ maka kesimpulannya adalah observasi ini tidak terjadi autokorelasi. c. Heteroskedastisitas

\begin{tabular}{|l|l|}
\multicolumn{2}{l}{ Uji Heteroskedastisitas } \\
\hline Prob.Chi-square & Keterangan \\
\hline 0,177 & Tidak terjadi heteroskedastisitas \\
\hline
\end{tabular}

Berdasarkan hasil pengujian heteroskedastisitas di atas dapat dilihat bahwa nilai Obs*R-squared Chi-Square sebesar 1,775 atau > 0,05 . Sehingga dapat disimpulkan model regresi tidak terjadi heteroskedastisitas.

d. Multikolinieritas

\begin{tabular}{|c|c|c|c|c|c|}
\hline & $\mathrm{X} 5$ & $\mathrm{X} 4$ & $\mathrm{X} 3$ & $\mathrm{X} 2$ & $\mathrm{X} 1$ \\
\hline $\mathrm{X} 5$ & 1.000000 & 0.018203 & 0.152383 & 0.016941 & 0.183655 \\
\hline $\mathrm{X} 4$ & 0.018203 & 1.000000 & -0.135748 & 0.390270 & 0.230461 \\
\hline $\mathrm{X} 3$ & 0.152383 & -0.135748 & 1.000000 & 0.248421 & -0.216228 \\
\hline $\mathrm{X} 2$ & 0.016941 & 0.390270 & 0.248421 & 1.000000 & -0.052988 \\
\hline $\mathrm{X} 1$ & 0.183655 & 0.230461 & -0.216228 & -0.052988 & 1.000000 \\
\hline & & & & & \\
\hline
\end{tabular}

Berdasarkan hasil pengujian multikolinearitas di atas dapat dilihat bahwa nilai korelasi atau derajat keeratan antar variabel independen kurang dari 0,90 (< 90\%). Sehingga dapat disimpulkan bahwa tidak terjadi multikolinearitas dalam model regresi ini.

\section{Hasil Uji Parsial (Uji T)}

\begin{tabular}{|c|c|c|c|c|}
\hline \multicolumn{5}{|c|}{ Hasil Uji t } \\
\hline Variable & Coefficient & Std. Error & t-Statistic & Prob. \\
\hline $\mathrm{C}$ & -0.609798 & 0.395525 & -1.541741 & 0.1308 \\
\hline $\mathrm{X} 1$ & -0.359188 & 0.124959 & -2.874458 & 0.0064 \\
\hline wh & A.L. & 156h & 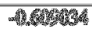 & 1945 \\
\hline 5 & 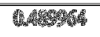 & Q71546) & 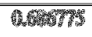 & (6) \\
\hline 政事 & . & 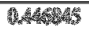 & W7LAM & 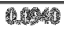 \\
\hline as & 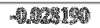 & 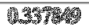 & 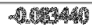 & axtos \\
\hline
\end{tabular}

a. Pengaruh Earning Per Share (EPS) (X1) terhadap tingkat Underpricing (Y)

$\begin{array}{ccr}\text { Hasil } & \text { pengujian } & \text { variabel } \\ \text { Earning } & \text { Per Share } & \text { (EPS) }\end{array}$ menunjukan nilai koefisien regresi sebesar -0,359 sehingga setiap kenaikan 1 satuan Earning Per Share akan menurunkan underpricing sebesar 0,359 atau sebaliknya. Diperoleh nilai probabilitas sebesar 0.006. Nilai probabilitas tersebut lebih kecil dari $\alpha=0,05$. Dengan demikian dapat disimpulkan bahwa Earning per 
Share signifikan berpengaruh terhadap tingkat underpricing saham saat penawaran saham perdana (IPO). Atau H1 diterima.

b. Pengaruh Debt To Equity Ratio (DER) (X2) terhadap tingkat Underpricing (Y)

Pengujian variabel Debt to Equity Ratio (DER) memperoleh niliai koefisien regresi sebesar 0,101 sehingga setiap kenaikan 1 satuan Debt to Equity ratio menurunkan tingkat underpricing saham sebesar 0,101 atau sebaliknya. Diperoleh nilai probabilitas sebesar 0,545. Nilai probabilitas tersebut lebih besar dari $\alpha=0,05$. Dengan demikian dapat disimpulkan bahwa Debt To Equity Ratio tidak signifikan berpengaruh terhadap tingkat underpricing. Atau $\mathrm{H} 2$ ditolak.

c. Pengaruh reputasi Underwriter (X3) terhadap tingkat Underpricing (Y)

Diperoleh nilai probabilitas sebesar 0,496. Nilai probabilitas tersebut lebih besar dari $\alpha=0,05$ artinya bahwa H3 ditolak dan disimpulkan bahwa reputasi underwriter tidak signifikan berpengaruh terhadap tingkat underpricing. Hasil pengujian variabel reputasi underwriter menunjukkan nilai koefisien regresi sebesar 0,489 sehingga setiap kenaikan 1 satuan variabel reputasi underwriter maka menaikan tingkat underpricing saham 0,489 atau sebaliknya.

d. Pengaruh reputasi Auditor (X4) terhadap tingkat Underpricing (Y)Nilai koefisien variabel reputasi auditor sebesar -0,766 maka setiap kenaikan 1 satuan reputasi auditor akan terjadi kenaikan tingkat underpricing saham sebesar 0,766 dan sebaliknya. Tingkat probabilitas sebesar 0,094. Nilai probabilitas tersebut lebih besar dari $\alpha=0,05$. Sehingga dapat disimpulkan bahwa reputasi auditor tidak signifikan berpengaruh terhadap tingkat underpricing, maka $\mathrm{H} 4$ ditolak.

e. Pengaruh jenis industri (X5) terhadap tingkat Underpricing (Y)

Tingkat koefisien regresi variabel jenis industri sebesar 0,028 maka setiap kenaikan 1 satuan variabel ini akan menaikkan tingkat underpricing saham sebesar 0,028. Probabilitas pada variabel jenis industri sebesar 0.933. Nilai probabilitas tersebut lebih besar dari $\alpha=0,05$ maka H5 ditolak dan dapat disimpulkan bahwa jenis industri tidak signifikan berpengaruh terhadap tingkat underpricing.

4. Hasil Uji Simultan (Uji F)

Hasil Uji Kelayakan Model (Uji F)
\begin{tabular}{|c|c|c|}
\hline F-statistik & Prob (F-statistik) & Alpha \\
\hline 3,912 & 0,005 & 0,05 \\
\hline
\end{tabular}

Hasil uji $\mathrm{F}$ menunjukkan nilai F-statistik sebesar 3,912 dengan probabilitas sebesar 0,005. Nilai probabilitas tersebut lebih kecil dari 0,05 sehingga dapat disimpulkan bahwa secara simultan terdapat pengaruh antara variabel-variabel bebas dengan variabel terikat atau dapat dikatakan bahwa variabel EPS, DER, reputasi underwriter, reputasi auditor, dan jenis industri secara simultan berpengaruh terhadap underpricing.

5. Hasil Uji Koefisien Determinasi

Hasil Uji Determinasi $\left(\mathbf{R}^{2}\right)$

\begin{tabular}{|l|c|}
\hline R-squared & 0,3230 \\
\hline \multicolumn{2}{|c|}{ Berdasarkan hasil pengujian di } \\
\hline
\end{tabular}
atas dapat dilihat bahwa nilai $\mathrm{R}$ square adalah 0,3230. Hal ini menjelaskan bahwa 32,30\% variabel dependen dapat dijelaskan oleh kelima variabel independen. Hal tersebut menunjukkan underpricing dapat dijelaskan oleh earning per share, debt to equity ratio, reputasi underwriter, reputasi auditor, jenis industri perusahaan. Sedangkan 
sisanya, 67,7\% dijelaskan oleh faktorfaktor lain di luar model penelitian.

\section{Pembahasan}

1. Pengaruh Earning Per Share (EPS) terhadap tingkat underpricing saham saat IPO.

Berdasarkan uji statistic diketahui bahwa variabel-variabel Earning Per Share (EPS) berpengaruh negatif terhadap tingkat underpricing saham pada saat IPO. Hal ini dapat dilihat dari nilai signifikansi sebesar $0,006<0,05$. Hasil penelitian ini menolak penelitian yang dilakukan Hayati (2013) dan Kurniawan (2012) yang mengemukakan bahwa Earning Per Share (EPS) tidak berpengaruh secara signifikan terhadap tingkat underpricing saham pada saat penawaran saham perdana di pasar saham. Namun penelitian yang dilakukan Irawati (2012) dan Hayati (2012) mendukung penelitian ini yang menyatakan bahwa earning per share berpengaruh terhadap tingkat underpricing saham pada penawaran umum perdana di pasar saham. EPS Menggambarkan laba yang diperoleh perusahaan per lembar sahamnya. EPS berhubungan dengan resiko dan performance perusahaan. Semakin mapan perusahaan semakin tinggi EPS yang dimilikinya dengan demikian semakin sedikit initial return yang diperoleh. Atau dengan kata lain ketika perusahaan memiliki laba per lembar saham lebih tinggi tingkat underpricing dapat diminimalisir sehingga investor akan mempertimbangkan faktor EPS untuk melakukan investasi selain itu

2. Pengaruh Debt To Equity Ratio (DER) terhadap tingkat underpricing saham saat IPO.

Hasil menunjukkan nilai signifikansi regresi variabel DER sebesar 0,545 lebih besar dari taraf signifikansi 0,05. Hasil penelitian ini mendukunghasil kesimpulan penelitian yang dilakukan Dwijayanti (2015) dan
Aini (2012) bahwa faktor Debt to Equity Ratio (DER) tidak berpengaruh terhadap tingkat underpricing saham saat IPO. Hal ini karena investor menganggap bahwa jika DER terlalu tinggi, maka perusahaan cenderung menggunakan dana hasil IPO untuk membayar hutang. Semakin tinggi angka DER maka diasumsikan perusahaan memiliki resiko yang semakin tinggi terhadap likuiditas perusahaannya.

3. Pengaruh reputasi underwriter terhadap tingkat underpricing saham saat IPO.

Berdasarkan uji statistik diketahui bahwa variabel reputasi underwriter tidak berpengaruh terhadap tingkat underpricing saham pada saat IPO. Hal ini dapat dilihat dari nilai signifikansi sebesar 0,496 lebih besar dari taraf signifikansi 0,05. Hasil penelitian ini mendukung penelitian yang dilakukan Lestari (2015) yang menyatakan bahwa reputasi underwriter tidak berpengaruh secara signifikan terhadap tingkat underpricing saham saat IPO. Sama halnya dengan penelitian yang dilakukan oleh Prastica (2012) dan Wahyusari (2013) yang menyatakan bahwa variabel reputasi underwriter tidak berpengaruh terhadap tingkat underpricing saham saat penawaran perdana. Namun penelitian yang dilakukan Hapsari (2012) dan Kristiantari (2013), tidak mendukung hasil penelitian ini, yang menyatakan bahwa reputasi underwriter berpengaruh negatif terhadap underpricingsaham saat penawaran perdana. Underwriter merupakan pihak yang ikut serta dalam menentukan harga saham dan bertanggungjawab atas penjualan saham, jika saham yang dijual masih tersisa maka underwriter sebagai penjamin emisi wajib untuk membelinya. Hal tersebut yang menyebabkan underwriter yang belum memiliki reputasi tinggi berusaha menekan harga saham agar saham 
tersebut terjual, sehingga mengakibatkan terjadinya underpricing. Namun berbeda dengan underwriter yang memiliki reputasi tinggi, mereka berani memberikan harga saham tinggi. Hal ini dinilai dapat mengurangi underpricing saat penawaran saham perdana.

4. Pengaruh reputasi auditor terhadap tingkat underpricing saham saat IPO

Berdasarkan output dari E-views besarnya nilai signifikansi 0,094 lebih besar dari taraf signifikansi 0,05. Hasil penelitian ini mendukung penelitian terdahulu yang dilakukan oleh Aini (2013), Kristiantari (2013) dan Bachtiar (2013), yang menyatakan bahwa reputasi auditor tidak mempunyai pengaruh terhadap underpricing pada saat penawaran saham perdana. Hal ini dapat dipengaruhi oleh rendahnya tingkat kepercayaan investor terhadap kinerja pihak auditor, walaupun perusahaan yang bersangkutan telah berusaha menggunakan jasa pengaudit dengan reputasi tinggi.

5. Pengaruh jenis industri terhadap tingkat underpricing saham saat IPO

Hasil uji t menunjukkan bahwa jenis industri tidak mempengaruhi tingkat underpricing saat IPO hal tersebut dapat dilihat dari besarnya nilai signifikansi variabel jenis industri (X5) yaitu 0,933 lebih besar dari 0,05 . Hal ini terjadi kemungkinan disebabkan karena investor menganggap bahwa setiap jenis industri memiliki tingkat resiko yang berbeda-beda dan tingkat ketidakpastian yang tidak sama satu sama lain. Kedua hal tersebut terjadi karena setiap industri baik manufaktur maupun non manufaktur memiliki karakteristik yang tidak sama. Temuan ini mendukung penelitian yang dilakukan Lestari (2015) dan Irawati (2012) bahwa jenis industri tidak berpengaruh terhadap tingkat underpricing saham.

KESIMPULAN DAN SARAN

\section{Kesimpulan}

1. Variabel Earning Per Share (EPS) signifikan berpengaruh terhadap variabel tingkat Underpricing. Hal ini dapat dilihat dari nilai probabilitas EPS $=0,006$ lebih kecil dari $\alpha=0,05$.

2. Variabel Debt to Equity Ratio (DER) tidak signifikan berpengaruh terhadapvariabel tingkat Underpricing. Hal ini dapat dilihat dari nilai probabilitas DER $=0,545$ lebih besar dari $\alpha=0,05$.

3. Variabel reputasi underwriter tidak signifikan berpengaruh terhadap variabel tingkat Underpricing. Hal ini dapat dilihat dari nilai probabilitas reputasi underwriter $=0,496$ lebih besar dari $\alpha=0,05$.

4. Variabel reputasi auditor tidak signifikan berpengaruh terhadap variabel tingkat Underpricing. Hal ini dapat dilihat dari nilai probabilitas reputasi auditor $=0,094$ lebih besar dari $\alpha=0,05$.

5. Variabel jenis industri tidak signifikan berpengaruh terhadap variabel tingkat Underpricing. Hal ini dapat dilihat dari nilai probabilitas jenis industri $=$ 0,9333 lebih besar dari $\alpha=0,05$

6. Hasil uji $F$ menunjukkan bahwa variabel Earning Per Share (EPS), Debt to Equity Ratio (DER), reputasi Underwriter, reputasi Auditor, dan jenis industri secara bersama-sama signifikan berpengaruh terhadap variabel tingkat Underpricing. Hal ini dapat kita lihat dari nilai tingkat signifikansi $=0,005$. Dengan demikian karena probabilitas $=0,005$ lebih kecil dibanding taraf signifikasi $\alpha=$ 0,05 . 


\section{Saran}

1. Penelitian yang akan datang diharapkan agar memperpanjang periode penelitian, supaya sampel penelitiannya semakin banyak.

2. Penelitian selanjutnya diharapkan dapat menambah variabel independen yang diduga dapat mempengaruhi underpricing saat penawaran saham perdana.

3. Bagi perusahaan hendaknya lebih banyak memberikan informasi kepadainvestor dan menghindari timbulnya asymetri informasi. Dengan demikian diharapkan perusahaan mampu untuk meminimalisir terjadinya underpricing.

4. Bagi investor hendaknya lebih banyak mencari informasi mengenai perusahaan, agar tidak salah dalam berinvestasi.

\section{DAFTAR PUSTAKA}

Aini, Shoviyah Nur. (2013). "FaktorFaktor Yang Mempengaruhi Underpricing Saham Pada Perusahaan IPO di BEI Periode 2007-2011". Jurnal Ilmiah Manajemen, Vol. 1, No. 1, Januari. Hal 91-99.

Ang, Robert. (1997). "Pintar Pasar Modal Indonesia". Jakarta: Mediasoft Indonesia.

Asakdiyah, Salamatun. (2006). "Manajemen Keuangan I: Alat Analisis dan Aplikasi". Yogyakarta: PPM UAD.

Bachtiar, Akbar. (2012). "Analisis Variabel-Variabel yang Mempengaruhi Underpricing pada Saat IPO di Bursa Efek Indonesia Perioda 2008-2010". Skripsi tidak diterbitkan. Semarang: Universitas Diponegoro.
Dwijayanti, Made dan Wirakusuma, Made. (2015). "Pengaruh Informasi Keuangan dan Non Keuangan Return Awal Perusahaan Yang Melakukan IPO”. E-jurnal Akuntansi Universitas Udayana, Vol 13, No 1, 2015.

Ghozali, Imam. (2011). Aplikasi Analisis Multivariate Dengan Program SPSS. Semarang: Badan Penerbit Universitas Diponegoro.

Hapsari, Vinantia A. (2012). "Analisis Faktor-Faktor yang Mempengaruhi Underpricing Saham pada Penawaran Umum Perdana di BEI Periode 2008-2010”. Skripsi tidak diterbitkan. UNDIP.

Hayati, Aulya dan Deannes Isnuwardhana. (2013). "Faktor-Faktor Yang Mepengaruhi Underpricing Pada Saham Perdana Di Bursa Efek Indonesia Tahun 2011-2013”. Telkom University.

Jogiyanto, H. M. (2000). "Teori Portofolio dan Analisis Investasi”. Yogyakarta: BPFE.

Kristiantari, I Dewa A. (2013). "Analisis Faktor-faktor Yang Mempengaruhi Underpricing Saham Pada Penawaran Saham Perdana Di Bursa Efek Indonesia”. Jurnal Ilmiah Akuntansi dan Humaniora, Vol 2, No 1, Oktober. Hal 787-794.

Kurniawan, Benny. (2007). "Analisis Pengaruh Variabel Keuangan dan Non Keuangan Terhadap Initial Return 7 Hari Setelah IPO (Study Empiris Di Perusahaan Non Keuangan yang Listing Di BEI Periode 2002-2006)". Tesis tidak diterbitkan. Semarang: Magister Manajemen, UNDIP.

Kurniawan, R Dimas Bayu. (2012).

"Analisis Faktor-Faktor Yang 
Mempengaruhi Tingkat

Underpricing Pada Perusahaan Go Publik Yang Terdaftar Di Bursa Efek Indonesia (BEI) Periode 20082009". Skripsi tidak diterbitkan. Yogyakarta: UAD.

Kusuma, Desta Rizky dan Ismanto, Deny. (2012). "MODUL PRAKTIKUM EViews". Yogyakarta: UAD.

Lestari, Anggelia Hayu. (2015). "Analisis FAktor-Faktor Yang Mempengaruhi Underpricing Saham Pada Penawaran Umum Perdana di BEI Periode 2012-2014 (Studi Pada Perusahaan yang Melakukan IPO di BEI Periode 2012-2014). Jurnal Administrasi Dan Bisnis (JAB), Vol 25. No 1. Hal 3-7.

Martalena dan Malinda. (2011). "Pengantar Pasar Modal". Yogyakarta: ANDI OFFSET.

Maryoto. (2007). "Pengaruh Variabel Keuangan (Return On Asset, Earning Per Share, Current Ratio, dan Financial Laverage) Perusahaan terhadap Underpricing". Skripsi Tidak Diterbitkan. Yogyakarta: UAD.

Prastica, Yurena. (2012). "Faktor-faktor yang Mempengaruhi Tingkat Underpricing pada Saat Penawaran Umum Saham Perdana”. Jurnal Ilmiah Mahasiswa Akuntansi, Vol. 1 No. 2 (Maret), hal. 99-105.

Purbarangga, Ade. (2013). "FaktorFaktor Yang Mempengaruhi Underpricing Saham Pada penawaran Umum Saham Perdana". Skripsi Tidak Diterbitkan. UNDIP.

Tandelilin, Eduardus. (2010). "Portofolio dan Investasi Teori dan Aplikasi". Edisi Pertama. Yogyakarta: Kanisius.
Wahyusari, Ayu. (2013). "Analisis Faktorfaktor Yang Mempengaruhi Underpricing Saham Saat IPO di BEI". Accounting Analysis Journal, Vol 2, No 4, 2013. Hal.387-394.

Yolana, Chastina dan Martani, Dwi. (2005). "Variabel-variabel Yang Mempengaruhi Fenomena Underpricing pada Penawaran Saham Perdana di BEJ Tahun 1994-2000. Makalah Seminar Nasional Akuntansi VIII Solo. 